\title{
JUURNAL.RU
}

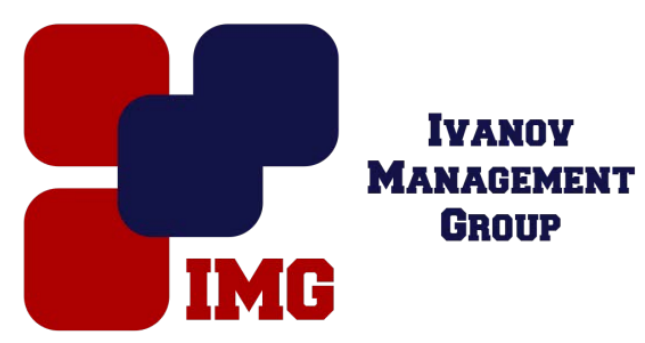

Чуйко A.C. Орловский государственный университет имени И.С. Тургенева

Орёл, Россия

doi: 10.18411/lj-31-03-2017-2-08

idsp 000001:lj-31-03-2017-2-08

\section{Проблемы и особенности систем автоматизации документооборота вуза и их решения}

\section{Аннотация}

В статье рассматриваются проблемы и особенности систем автоматизации документооборота, касающиеся регистрации и контроля организационнораспорядительных документов вуза. Предлагается способ решения этих проблем и оценивается его эффективность.

Ключевые слова: системы электронного документооборота (СЭД), ОРД, регистрация документа, контроль исполнения документа, журнал регистрации, жизненный цикл документа

В настоящее время вузы активно переходят от бумажного документооборота к использованию систем электронного документооборота (СЭД). Это связано с тем, что поток документов становится все больше и больше, и вручную управлять им становится труднее. СЭД имеют ряд преимуществ: возможность ведения единой базы документов, что позволяет исключить дублирование документов; эффективно организованная система поиска документа; контроль движения и исполнения документов; регистрация документов и ведение электронных журналов регистрации документов; возможность отслеживать весь жизненный цикл документа.

На данный момент рынок программного обеспечения предоставляет большое количество СЭД. Отличаются они друг от друга структурой, ценой, функциональностью, способом реализации. Однако большинство вузов предпочитают разрабатывать свою собственную автоматизированную систему 
документооборота. Это связано с тем, что после приобретения коммерческой системы вуз может столкнуть со следующими проблемами. Первая и самая важная проблема - это проблема внедрения, связанная с настройкой системы на специфику вуза, с интеграцией системы с другими используемыми вузом информационными системами. Вторая проблема, заключается в том, что может потребоваться дополнительные расходы, связанные с покупкой нового программного обеспечения (платформы), клиентской лицензии, технической поддержки. Не маловажной проблемой выступает человеческий фактор. Многие сотрудники боятся чего-то нового, и отказываются обучаться, разбираться и работать с такой системой.

Чтобы избежать перечисленных проблем, необходимо разработать узкопрофильную СЭД, направленную на специфику работы вуза. Так как основным видом документов в вузе являются организационно-распорядительные документы, а руководство, контроль за ведением делопроизводства в вузе осуществляет Общий отдел, то необходимо автоматизировать в первую очередь, деятельность этого отдела, которые выполняет такие важные функции, как регистрацию и контроль документов. Также в каждом вузе предусмотрен стандарт организации, по которому выполняется ведение документооборота и по которому работают сотрудники. Поэтому необходимо автоматизировать систему, опираясь на данный стандарт и предпочтения сотрудников, выявленных с помощью опросов, анкетирования. Следует проводить разработку системы совместно с сотрудниками Общего отдела, реализовывать пробные версии системы и позволять им тестировать их для выявления ошибок и недостатков в работе системы. Разработку системы необходимо проводить поэтапно, чтобы в итоге получить целостную систему, имеющую следующие важные функции:

- разграничение прав доступа к системе. Эта функция определяет разграничение пользователей на группы, каждая из которых будет иметь свои функции и свой интерфейс;

- создание документа и формирование поручения о создании документа;

- ведение электронного хранения документов;

- поиск документа в электронном архиве документов;

- регистрация документов; 
- адресная рассылка документов с подтверждением адресатом получения;

- уведомление адресата о рассылке через электронную почту;

- формирование справки о неисполненных документах;

- ведение электронного журнала регистрации;

- контроль исполнения документов.

В заключение следует сказать, что решения, предложенные для устранения проблем автоматизации документооборота вуза, позволят разработать систему, направленную на специфику работы вуза, привлечь сотрудников к участию в разработке и в дальнейшей работе с системой. Таким образом, уменьшится нагрузка на сотрудников путем уменьшения объема создания и регистрации документов, появится возможность отслеживать весь жизненный цикл документов, и тем самым повысится эффективность и производительность труда при работе с документами.

\section{Литература}

1. Кириллов А.Г. Организационные условия эффективной информатизации управления вузом // Ярославский педагогический вестник, 2013г. - №4. - С.59-64

2. Соколов Е.А., Середа С.Н. Информационный сервис электронного документооборота ВУЗА // Современные проблемы науки и образования, 2012г. - №5.

3. СТО ОрелГТУ 61-01-01-2010 [Текст]: «Стандарт организации. Система менеджмента качества. Управление организационно-распорядительной документацией». Орел:ОрелГТУ, 2010. - 72с. 